\title{
PENGARUH PENGETAHUAN INVESTASI, MANFAAT INVESTASI, MOTIVASI INVESTASI, MODAL MINIMAL INVESTASI DAN RETURN INVESTASI TERHADAP MINAT INVESTASI DI PASAR MODAL (Studi pada Mahasiswa Fakultas Ekonomi dan Bisnis Universitas Mataram)
}

\author{
Burhanudin ${ }^{1}$ Siti Aisyah Hidayati ${ }^{2}$ Sri Bintang Mandala Putra ${ }^{3}$ \\ ${ }^{1}$ Fakultas Ekonomi dan Bisnis Universitas Mataram burhanudin mtr@yahoo.com \\ ${ }^{2}$ Fakultas Ekonomi dan Bisnis Universitas Mataram hidayati250573@yahoo.com \\ ${ }^{3}$ Fakultas Ekonomi dan Bisnis Universitas Mataramsbintangmandalap@gmail.com
}

\begin{tabular}{ll|lll}
\hline Article history & \multicolumn{3}{l}{} \\
\hline Dikirim tanggal & $: 14 / 12 / 2020$ & Diterima tanggal & $:$ & $06 / 03 / 2021$ \\
Revisi pertama tanggal & $: 27 / 02 / 2021$ & Tersedia online tanggal & $:$ & $20 / 03 / 2021$ \\
\hline
\end{tabular}

\begin{abstract}
ABSTRAK
Penelitian ini dilakukan untuk menguji pengaruh pengetahuan investasi, manfaat investasi, motivasi investasi, modal minimal investasi dan return investasi terhadap minat investasi di pasar modal studi pada mahasiswa Fakultas Ekonomi dan Bisnis Univestitas Mataram. Jenis penelitian ini adalah assosiatif dengan metode kuantitatif. Sampel dalam peneltian ini diperoleh dengan metode cluster sampling. Berdasarkan kriteria yang ada didapatkan 60 mahasiswa fakultas ekonomi dan bisnis yang menjadi sampel dalam penelitian ini yaitu jurusan akuntansi sebanyak 36 mahasiswa, jurusan manajemen 18 mahasiswa dan jurusan ekonomi pembangunan 6 mahasiswa. Sumber data yang digunakan dalam penelitian ini adalah data primer dengan teknik analisis regresi linear berganda. Hasil penelitian menunjukkan bahwa koefisien pengetahuan investasi, motivasi investasi dan modal minimal investasi bernilai postif tetapi tidak berpengaruh secara signifikan, variabel lain seperti manfaat investasi dan return investasi memiliki pengaruh positif dan signifikan. Berdasarkan uji $\mathrm{F}$ menunjukkan kelayakan dalam model diperoleh nilai signifikansi sebesar $0,000<0,05$, menunjukkan bahwa uji model ini layak untuk digunakan pada penelitian. Kemampuan prediksi dari kelima variabel terhadap minat investasi sebesar $50.5 \%$ sebagaimana ditunjukkan oleh besarnya adjusted $R$ square sebesar 0.505 sedangkan sisanya $49.5 \%$ dijelaskan olef faktor lain yang tidak dimasukkan kedalam model penelitian.
\end{abstract}

Kata kunci: Pengetahuan investasi, Manfaat Investasi, Motivasi Investasi, Modal Minimal Investasi, Return Investasi, Minat Investasi

\section{ABSTRACT}

This research was conducted with the aim to examine the effect of variable Investment Knowledge, Investment Benefit, Investment Motivation, Investment Capital Minimum and Investment Return on Investment Interest in Capital Market Study in Faculty of Economics and Business University of Mataram Student. This type of research is a associative research with quantitative methods. The sample in this study was obtained by cluster sampling method. Based on the existing criteria, there were 60 student of Faculty Economics and Business which is the sample in this study is 36 Accounting Student, 18 Management student and 6 Economics Student that became the study sample. The data source used in this study is primary data, the data analysis technique used is multiple linear regression. The results showed that the Investment Knowledge, Investment Motivation and Investment Minimum Capital whose coefficients are positive but have no significant effect on Investment Interest. Other variable in this research Investment Benefits and 
Investment Return coefficient was positive and significant towards the Investment Interest. Based on the results of the F test showed that the feasibility in the model obtained a significance value of $0,000<0.05$, indicating that the test model is feasible to be used in research. The predictive ability of the five variables on the Investment Interest of $50.5 \%$ as shown by the size of the adjusted $R$ square of 0.505 while the remaining $49.5 \%$ is explained by other factors not included in the research model.

Keywords: Investment Knowledge, Investment Benefits, Investment Motivation, Investment Capital Minimum, Investment Return, Investment Interest.

\section{PENDAHULUAN}

\section{Latar Belakang}

Pasar modal mempunyai peranan penting dalam pembangunan ekonomi suatu negara. Dengan adanya pasar modal investor individu maupun badan usaha dapat menyalurkan kelebihan dana yang dimilikinya untuk diinvestasikan di pasar modal, dan para pengusaha dapat memperoleh dana tambahan modal untuk memperluas jaringan usahanya dari para investor yang berada di pasar modal (Yuliana, 2010: 34).

Anoraga (2001:12) menyatakan manfaat pasar modal bisa dirasakan baik oleh investor, emiten, pemerintah maupun lembaga penunjang. Manfaat pasar modal bagi emiten yaitu Jumlah dana yang dihimpun bisa berjumlah besar. Manfaat pasar modal bagi investor yaitu berupa capital gain, memperoleh dividen saham dan bunga obligasi, mempunyai hak suara dalam RUPS dapat dengan mudah mengganti instrument investasi, serta dapat sekaligus melakukan investasi dalam beberapa instrument yang mengurangi risiko (portofolio)

Pengetahuan Investasi merupakan pemahaman yang harus dimiliki seseorang mengenai berbagai aspek mengenai investasi dimulai dari pengetahuan dasar penilaian investasi, tingkat risikonya, dan tingkat pengembalian (return) investasi. karena semakin banyak ilmu yang didapatkan mengenai investasi baik itu melalui pembelajaran maupun sosialisasi dari pasar modal maka semakin besar keinginan seseorang dalam melakukan investasi di pasar modal.

Penelitian yang dilakukan oleh Karima (2018) menyatakan bahwa manfaat investasi berpengaruh terhadap minat investasi hal ini sejalan dengan penelitian Riyadi (2016), sedangkan penelitian yang dilakukan oleh Hermawanti (2018) adalah sebaliknya dimana manfaat investasi tidak berpengaruh terhadap minat investasi. Beberapa manfaat investasi yaitu membantu meningkatkan kesejahteraan hidup, sebagai indikator pembangunan ekonomi, sebagai asset masa depan yang baik serta dapat memberikan penghasilan tetap. Hal ini dipicu oleh kesadaran setiap individu akan pentingnya investasi semakin tinggi.

Penelitian yang dilakukan oleh Pajar (2017) menyatakan bahwa motivasi investasi berpengaruh terhadap minat investasi, hal ini sejalan dengan penelitian yang dilakukan oleh Nisa (2017), Malik (2017) dan Riyadi (2016) sedangkan penelitian yang dilakukan oleh Hermawanti (2018) menyatakan bahwa motivasi investasi tidak berpengaruh terhadap minat investasi, hal ini sama dengan penelitian yang dilakukan oleh Karima (2018). Menurut Martoyo (2007) motivasi pada dasarnya adalah "proses untuk mencoba mempengaruhi seseorang agar melakukan sesuatu yang kita inginkan".

Penelitian yang dilakukan oleh Riyadi (2016) menyatakan bahwa modal minimal investasi berpengaruh terhadap minat investasi, sedangkan menurut Hermawanti (2018) menyatakan bahwa modal minimal investasi tidak berpengaruh terhadap minat investasi. Modal minimal investasi menurut Daniel (2016) dalam Pajar (2017) yang menyatakan bahwa modal investasi minimal diibaratkan sebuah diskon besar-besaran yang akan 
memicu minat berbelanja. Dalam hal dihubungkan dengan investasi bahwa dengan modal yang sedikit dalam memulai investasi maka akan menarik minat investasi.

Penelitian yang dilakukan oleh Tandio (2016) menyatakan bahwa return investasi berpengaruh terhadap minat investasi hal ini sejalan dengan penelitian yang dilakukan Hermawanti (2018) dan penelitian yang dilakukan oleh Susilowati (2017) sedangkan menurut Karima (2018) menyatakan bahwa return investasi tidak berpengaruh terhadap minat investasi hal ini juga diperoleh dalam penelitian Riyadi (2016).

Jogiyanto (2010) menyatakan bahwa return dapat berupa return realisasi (realizedreturn, dihitung menggunakan data historis) yang sudah terjadi atau return ekspektasi (expectedreturn) yang belum terjadi tetapi diharapkan akan terjadi di masa mendatang. Return dan risiko dalam investasi memiliki hubungan positif, yaitu semakin tinggi risiko maka return yang diharapkan juga semakin tinggi. Teori return dan juga mendukung hasil ini. Semakin besar return yang mungkin diperoleh maka semakin besar pula minat investasi.

Dalam penelitian ini hanya lima faktor yang ingin diketahui yaitu Pengetahuan Investasi, Manfaat Investasi, Motivasi Investasi, Modal Minimal Investasi dan Return Investasi apakah memiliki pengaruh terhadap minat investasi atau tidak, alasan pemilihan lima variabel tersebut adalah keterkaitan dengan objek penelitian di fakultas ekonomi dan bisnis dimana mahasiswa tersebut sudah menjadi investor di pasar modal dan telah banyak mengikuti rangkaian sosialisasi yang diadakan oleh Bursa Efek Indonesia Kantor Perwakilan Nusa Tenggara Barat, hal ini juga di dukung oleh penelitian terdahulu yang menyatakan bahwa lima faktor tersebut memiliki pengaruh terhadap minat investasi mahasiswa di pasar modal. Namun dalam beberapa penelitian terdahulu terdapat ketidak selarasan (research gap)

Bursa Efek Indonesia merupakan suatu wadah bagi investor yang ingin melakukan investasi di pasar modal atau di pasar sekunder. Bursa Efek Indonesia memiliki berbagai macam pilihan perusahaan yang sudah go publik yang melakukan penjualan saham untuk menambah modal operasional perusahaan. mahasiswa atau masyarakat yang ingin menjadi investor bisa melakukan investasi saham di beberapa tempat yang sudah disediakan oleh pihak bursa efek indonesia di beberapa kantor perwakilan atau di beberapa unit kerjasama Galeri Investasi di berbagai Perguruan tinggi yang telah melakukan Kerjasama, diantaranya Galeri Investasi atau pojok bursa di Fakultas Ekonomi dan Bisnis Universitas Mataram. Adapun lembaga atau organisasi yang menjadi tanggung jawab melaksanakan tugas galeri investasi yaitu Kelompok Studi Pasar modal merupakan organisasi yang terstruktur yang menjadi penanggung jawab galeri investasi tersebut.

Tabel 1. Jumlah Nasabah Galeri Investasi Universitas Mataram

\begin{tabular}{|c|c|}
\hline Tahuan & Jumlah Investor (Orang) \\
\hline 2017 & 96 \\
\hline 2018 & 231 \\
\hline September 2019 & 277 \\
\hline
\end{tabular}

Sumber: Galeri Investasi Universitas Mataram 2019 (data diolah).

Mengacu pada tabel 1 menunjukkan populasi dari Fakultas Ekonomi dan Bisnis Universitas Mataram yang telah menjadi investor dan tertarik melakukan investasi di Pasar Modal. Investasi dalah bentuk saham menunjukkan ikut andil dalam pembangunan ekonomi secara global dan tentunya rasa kepemilikan atas perusahaan, hal ini juga dipicu 
oleh modal minimum yang ditawarkan sekuritas untuk membuka rekening akun saham, hanya sebesar Rp100.000.

\section{Rumusan Masalah}

Berdasarkan paparan diatas, maka dalam penelitian ini dapat dirumuskan beberapa rumusan masalah penelitian yaitu: Apakah Pengetahuan Investasi, manfaat Investasi, Motivasi Investasi, Modal Minimal Investasi, dan Return Investasi berpengaruh terhadap minat investasi di pasar modal?

\section{KAJIAN PUSTAKA}

Pengertian Theory of Reasoned Action (Teori Tindakan Beralasan) Fishbein dan Adjen dalam Azizah (2014: 24) dalam (Riyadi, 2016), yaitu: "Perilaku manusia dipengaruhi oleh kehendak/niat/minat. Minat merupakan keinginan individu untuk melakukan perilaku tertentu sebelum perilaku tersebut dilaksanakan. Adanya niat/minat untuk melakukan suatu tindakan akan menentukan apakah kegiatan tersebut akhirnya di lakukan". Theory of reasoned action (Teori Tindakan Beralasan) menghubungkan antara keyakinan, sikap, kehendak dan perilaku. Dimana kehendak merupakan prediktor terbaik dari suatu tindakan, dapat diartikan jika ingin mengetahui apa yang akan dikerjakan oleh seseorang sebaiknya mengetahui kehendak orang tersebut. Konsep terpenting pada teori ini, yaitu mempertimbangkan sesuatu yang dianggap penting.

Selanjutnya teori perilaku beralasan diperluas dan dimodifikasi oleh Ajzen dalam Jogiyanto (2007) dinamai Teori Perilaku Terencana (theory of planned behavior) inti teori ini mencakup tiga hal yaitu keyakinan tentang kemungkinan hasil dan evaluasi dari perilaku tersebut (behavioral beliefs), keyakinan tentang norma yang diharapkan dan motivasi untuk memenuhi harapan tersebut (normative beliefs) serta adanya faktor yang dapat mendukung atau menghalangi perilaku dan kesadaran akan kekuatan faktor tersebut (control beliefs).

Investasi merupakan istilah yang berkaitan dengan keuangan dan ekonomi. Istilah tersebut berkaitan dengan akumulasi suatu bentuk aktiva dengan harapan akan mendapatkan keuntungan dimasa mendatang. Sebelum mengenal akan adanya investasi banyak orang yang hanya menyisihkan uangnya dalam bentuk tabungan, akan tetapi seiring perkembangan zaman orang-orang mulai meninggalkan metode kuno tersebut dan menggantinya dengan, membeli saham, obligasi, emas, reksadana, yang sekiranya memberikan keuntungan yang menjanjikan dimasa mendatang. Sebelum melakukan investasi pada satu instrumen investasi, tentunya investor harus mengetahui dan mempelajari setiap hal yang berkaitan dengan sebuah investasi.

Pajar (2016) menyatakan bahwa faktor-faktor yang mempengaruhi minat investasi adalah motivasi investasi dan pengetahuan investasi, Karima (2018) menyatakan bahwa faktor yang mempengaruhi minat investasi adalah manfaat investasi, Julaika (2017) menyatakan bahwa faktor faktor yang mempengaruhi minat investasi adalah modal minimal investasi dan motivasi investasi hal ini juga diungkapkan oleh Riyadi (2016) menyatakan bahwa faktor faktor yang mempengaruhi minat investasi adalah man faat investasi, modal minimal investaski dan motivasi investasi. Hermawanti (2018) menyatakan bahwa faktor faktor yang mempengaruhi minat invetsasi di pasar modal adalah return investasi dan edukasi pasar modal hal ini juga diungkapkan oleh Tandio (2016) bahwa return investasi merupakan faktor faktor yang mempengaruhi minat investasi. 
Dalam proses keputusan berinvestasi, diperlukannya pengetahuan tentang pengembalian, resiko, tipe produk investasi, untuk mendapatakan investasi yang lengkap (Siahaan, N.M, 2011). Menurut Kusumawati (2011) untuk melakukan investasi di pasar modal diperlukan pengetahuan yang cukup, pengalaman serta naluri bisnis untuk menganalisis efek - efek mana saja yang akan dibeli. Pengetahuan yang memadai sangat diperlukan, seperti pada instumen investasi saham, hal -hal yang sangat penting untuk diketahui adalah bagaimana menilai kinerja perusahaan yang bersangkutan untuk beberapa tahun belakangan. Pengetahuan investasi sangat diperlukan untuk menghindari terjadinya kerugian saat berinvestasi di pasar modal. Pengetahuan investasi juga sangat diperlukan untuk memperoleh return yang maksimal dari investasi yang dilakukan.

Motivasi didefinisikan sebagai proses dimana individu mengenal kebutuhannya dan mengambil tindakan untuk memuaskan kebutuhan tersebut. Dalam kandungannya bahwa motivasi merupakan suatu proses dan proses ini dapat menjelaskan perbedaan dalam intensitas perilaku konsumen (investor). Kandungan lainnya dari definisi tersebut bahwa motivasi merupakan dorongan, yaitu dorongan bagi manusia untuk mengambil tindakan tertentu dalam upaya memuaskan kebutuhannya. David MecClelland mengembangkan teori motivasi yang dikenal dengan McClelland's theory of learned needs. Teori ini menyatakan bahwa ada tiga kebutuhan dasar yang memotivasi seseorang individu untuk berperilaku yaitu 1) kebutuhan untuk sukses, 2) kebutuhan untuk afiliasi (membina hubungan sesame), 3) kebutuhan kekuasaan. Dalam kaitan teori tersebut dalam investasi, investor termotivasi untuk berinvestasi dalam pemenuhan kebutuhan diri (kesuksesan dan return) juga membantu perkembangan perekonomian dalam afiliasi dengan emiten atau perusahaan terbuka, dan juga untuk kebutuhan kekuasaan yang terkait dengan menjaga keterpenuhan kebutuhan diri atau keluarga dalam jangka waktu yang lama (keturunan) dan bisa juga ditafsirkan untuk pengembangan kekuasaan dalam investasi dalam rangka menjaga kestabilan perekonomian dengan menjadi majoritas pemegang saham.

Return merupakan hasil yang diperoleh dari penanaman modal dalam sebuah investasi. Jogiyanto (2017) menyatakan bahwa return dapat berupa return realisasi (realized return, dihitung menggunakan data historis) yang sudah terjadi atau return ekspektasi (expectedreturn) yang belum terjadi tetapi diharapkan akan terjadi di masa mendatang. Return dan risiko dalam investasi memiliki hubungan positif, yaitu semakin tinggi risiko maka return yang diharapkan juga semakin tinggi.

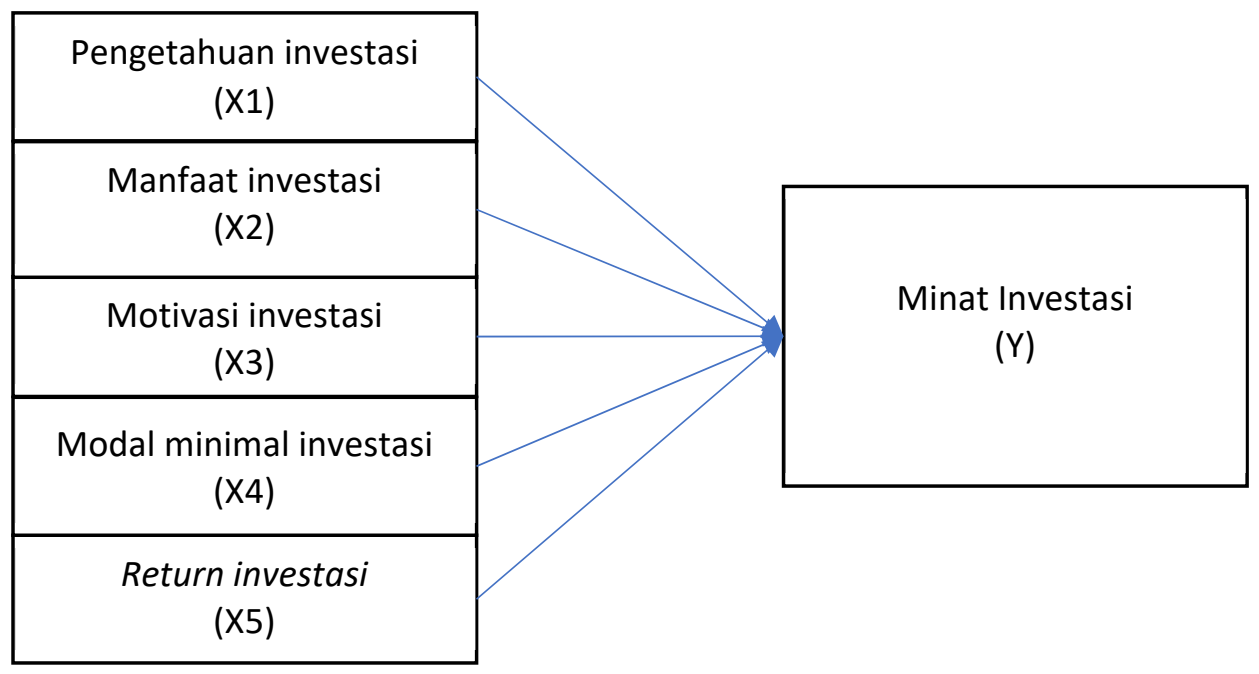

Gambar 1. Kerangka Konseptual 


\section{METODE PENELITIAN}

Jenis penelitian yang digunakan adalah penelitian asosiatif yang bertujuan untuk mengetahui apakah ada pengaruh pengetahuan investasi, manfaat investasi, motivasi investasi, return investasi dan modal investasi minimal terhadap minat investasi mahasiswa di pasar modal pada Fakultas Ekonomi dan Bisnis Universitas Mataram. Lokasi penelitian yang diambil oleh peneliti adalah Fakultas Ekonomi dan Bisnis Universitas Mataram yang terletak di Jl. Majapahit no 62 Mataram.

Populasi penelitian adalah mahasiswa Fakultas Ekonomi dan Bisnis Universitas Mataram yang terdiri dari jurusan Ilmu Ekonomi dan Studi Pembangunan, jurusan Manajemen dan Jurusan Akuntansi angkatan 2016 sampai 2018 yang sudah mengampu mata kuliah Manajemen Keuangan sebanyak 277 mahasiswa. Variabel penelitiannya ada 6 ( 5 independen dan 1 dependen), maka jumlah anggota sampel $=10 \times 6=60$. Metode pemilihan sampel menggunakan Cluster Sampling. Jumlah responden yang terpilih berdasarkan jurusan sebagai berikut S1 Akuntansi $=36$ orang, S1 Manajemen $=18$ orang dan S1 Ekonomi Pembangunan 6 orang.

Teknik pengumpulan data yaitu wawancara yaitu usaha untuk mengumpulkan informasi dengan mengajukan sejumlah pernyataan secara lisan untuk dijawab secara lisan pula, berdasarkan alat pengumpulan data kuesioner atau daftar pernyataan.

\section{Definisi Operasional Variabel}

Untuk mendefinisikan suatu variabel terkait dengan penelitian maka dibuat beberapa pengertian batasan operasional

Tabel 2. Definisi Operasional Variabel

\begin{tabular}{|c|c|c|c|}
\hline No & Variabel & Indikator & Item \\
\hline 1. & $\begin{array}{l}\text { Pengetahuan Investasi } \\
\text { merupakan pemahaman } \\
\text { yang harus dimiliki oleh } \\
\text { seseorang mengenai } \\
\text { berbagai aspek yang } \\
\text { meliputi investasi, yang } \\
\text { dapat diperoleh melalui } \\
\text { mata kuliah manajemen } \\
\text { keuangan dan Sekolah } \\
\text { Pasar Modal yang } \\
\text { diadakan oleh Bursa } \\
\text { Efek Indonesia. }\end{array}$ & $\begin{array}{l}\text { 1. Pentingnya Pengetahuan } \\
\text { dasar investasi } \\
\text { 2. Sekolah pasar modal } \\
\text { 3. Mata kuliah yang } \\
\text { berkaitan } \\
\text { 4. Pemahaman dasar } \\
\text { investasi }\end{array}$ & $\begin{array}{l}\text { 1. Sebagai calon investor, } \\
\text { pengetahuan dasar tentang investasi } \\
\text { sangat penting. } \\
\text { 2. Sekolah pasar modal membantu } \\
\text { investor untuk menambah } \\
\text { pengetahuan investasi. } \\
\text { 3. Mata kuliah Manajemen Keuangan, } \\
\text { membantu saya dalam memahami } \\
\text { jenis investasi. } \\
\text { 4. Pemahaman tentang pengetahuan } \\
\text { dasar investasi wajib dikuasai } \\
\text { sebelum melakukan investasi }\end{array}$ \\
\hline 2 & $\begin{array}{l}\text { Manfaat Investasi adalah } \\
\text { sesuatu yang didapatkan } \\
\text { oleh penanam modal } \\
\text { atau investor saat } \\
\text { berinvestasi yaitu } \\
\text { potensi penghasilan } \\
\text { jangka panjang, } \\
\text { memberikan penghasilan } \\
\text { tetap dan meningkatkan } \\
\text { aset serta memenughi } \\
\text { kehidupan dimasa } \\
\text { depan. }\end{array}$ & 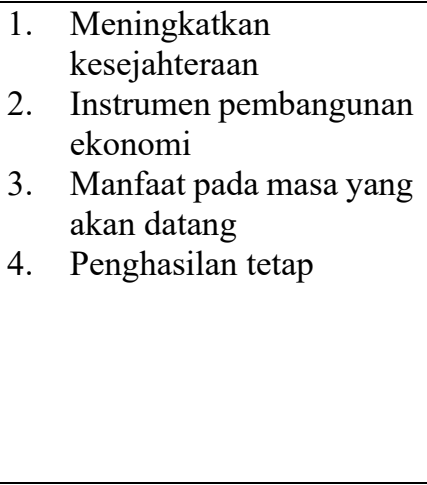 & \begin{tabular}{|l} 
1. \\
Menurut saya investasi dapat \\
membantu meningkatkan \\
kesejahteraan. \\
2. $\begin{array}{l}\text { Menurut saya investasi saham } \\
\text { merupakan instrumen penting } \\
\text { dalam pembangunan ekonomi }\end{array}$ \\
3. Saya meyakini bahwa dengan \\
berinvestasi akan memberikan \\
manfaat di masa yang alan datang. \\
4. Saya yakin dengan berinvestasi \\
dapat memberikan penghasilan \\
tetap
\end{tabular} \\
\hline 3. & $\begin{array}{l}\text { Motivasi Investasi } \\
\text { adalah keadaan dalam } \\
\text { pribadi seseorang atau } \\
\text { pengaruh lingkungan }\end{array}$ & $\begin{array}{l}\text { 1. Kepemilikan perusahaan } \\
\text { 2. Membantu } \\
\text { perkembangan } \\
\text { perusahaan }\end{array}$ & $\begin{array}{l}\text { 1. Dengan berinvestasi saham di pasar } \\
\text { modal, berarti saya memiliki } \\
\text { perusahaan dimana saya } \\
\text { berinvestasi }\end{array}$ \\
\hline
\end{tabular}

18 | Pengaruh Pengetahuan Investasi, Manfaat Investasi... 


\begin{tabular}{|c|c|c|c|}
\hline No & Variabel & Indikator & Item \\
\hline & $\begin{array}{l}\text { sekitar yang mendorong } \\
\text { keinginan individu } \\
\text { tersebut untuk } \\
\text { melakukan kegiatan } \\
\text { kegiatan tertentu untuk } \\
\text { berinvestasi dengan } \\
\text { tujuan untuk menjadi } \\
\text { bagian dalam pendanaan } \\
\text { perusahaan serta } \\
\text { membantu } \\
\text { perkembangan } \\
\text { perusahaan. }\end{array}$ & $\begin{array}{l}\text { 3. Pengaruh lingkungan } \\
\text { keluarga } \\
\text { 4. Kebutuhan terpenuhi }\end{array}$ & \begin{tabular}{|l} 
2. \\
Dengan berinvestasi berarti saya \\
membantu perusahaan untuk \\
berkembang. \\
3. Saya akan berinvestasi apabila \\
rekan, kerabat dan orang yang saya \\
kenal melakukan investasi di pasar \\
modal \\
4. Saya akan berinvestasi apabila \\
kebutuhan saya telah terpenuhi.
\end{tabular} \\
\hline 4. & $\begin{array}{l}\text { Modal minimal investasi } \\
\text { merupakan syarat dan } \\
\text { ketentuan dalam } \\
\text { membuka rekening akun } \\
\text { perdana untuk } \\
\text { berinvestasi di Pasar } \\
\text { modal. Di beberapa } \\
\text { sekuritas saat ini, dana } \\
\text { awal yang harus } \\
\text { disetorkan untuk } \\
\text { membuat akun cukup } \\
\text { yakni Rp100.000. }\end{array}$ & $\begin{array}{ll}\text { 1. } & \text { Modal Rp. } 100.000 \\
\text { 2. } & \text { Investasi terjangkau } \\
\text { 3. } & 1 \text { lot } 100 \text { lembar saham } \\
\text { 4. } & \text { Bebas dalam } \\
& \text { mengurangi dan } \\
\text { menambah saham }\end{array}$ & \begin{tabular}{|l} 
1. Saat ini perusahaan sekuritas \\
banyak yang menerapkan modal \\
investasi miniml sebesar Rp \\
100.000,- untuk memulai adanya \\
modal investasi minimal ini \\
memudahkan saya untuk memulai \\
investasi di pasar modal. \\
2. Sebagai salah satu instrumen \\
investasi, untuk memulai investasi \\
di pasar modal cukup terjangkau. \\
3ursa Efek Indonesia selaku \\
pengelola efek telah merubah \\
peraturan mengenai harga minimal \\
saham yang dapat dibeli dan telah \\
mengubah satuan lot yang tadinya 1 \\
lot 500 lembar saham \\
menjadi 1 lot 100 lembar saham, \\
dengan adanya perubahan ini \\
investasi yang harus dikeluarkan \\
menjadi sangat terjangkau. \\
Sebagai investor saya bebas untuk \\
mengurangi dan menambah modal \\
investasi saya dipasar modal.
\end{tabular} \\
\hline 5. & $\begin{array}{l}\text { Return Investasi } \\
\text { merupakan tingkat } \\
\text { keuntungan atau tingkat } \\
\text { pengembalian yang akan } \\
\text { didapatkan oleh } \\
\text { investor, return investasi } \\
\text { yang diperoleh adalah } \\
\text { Capital Gain dan } \\
\text { Dividen }\end{array}$ & 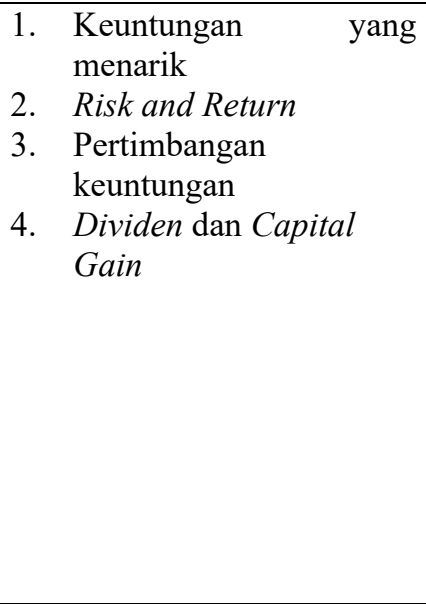 & \begin{tabular}{|l} 
1. \\
Dengan berinvestasi dipasar modal \\
memberikan keuntungan yang \\
menarik dan kompetitif. \\
2. $\begin{array}{l}\text { Menurut saya investasi saham di } \\
\text { pasar modal memberikan } \\
\text { keuntungan yang besar sesuai } \\
\text { dengan risiko yang ada. }\end{array}$ \\
3. $\begin{array}{l}\text { Jumlah keuntungan yang dapat } \\
\text { diperoleh dari investasi di pasar }\end{array}$ \\
modal terjadi pertimbangan saya \\
untuk berinvestasi di pasar modal \\
4. Saya mengetahui bahwa dividen \\
dan capital gain merupakan \\
keuntungan yang didapat dari \\
investasi saham pasar modal.
\end{tabular} \\
\hline 6. & $\begin{array}{l}\text { Minat Investasi } \\
\text { merupakan hasrat atau } \\
\text { keinginan yang kuat } \\
\text { pada seseorang untuk } \\
\text { mempelajari segala hal } \\
\text { atau menggali informasi } \\
\text { yang berkaitan dengan } \\
\text { investasi hingga pada }\end{array}$ & $\begin{array}{ll}\text { 1. } & \text { Informasi investasi } \\
\text { 2. } & \text { Menjanjikan Return } \\
\text { 3. } & \text { Investasi yang menarik }\end{array}$ & \begin{tabular}{|l} 
1. \\
Saya tertarik berinvestasi di pasar \\
modal karena berbagai informasi \\
yang saya dapatkan tentang \\
investasi di pasar modal \\
2. $\begin{array}{l}\text { Saya berminat investasi di pasar } \\
\text { modal karena investasi di pasar } \\
\text { modal sangat menjanjikan }\end{array}$
\end{tabular} \\
\hline
\end{tabular}




\begin{tabular}{|c|l|l|l|}
\hline No & \multicolumn{1}{|c|}{ Variabel } & Indikator & \multicolumn{1}{|c|}{ Item } \\
\hline & $\begin{array}{l}\text { tahap mempraktikannya } \\
\text { atau berinvestasi. }\end{array}$ & & $\begin{array}{l}\text { 3. } \\
\text { Saya sudah mencari informasi } \\
\text { mengenai investasi di pasar modal. } \\
\text { 4. } \begin{array}{l}\text { Menurut saya investasi di pasar } \\
\text { modal merupakan investasi yang } \\
\text { menarik }\end{array}\end{array}$ \\
\hline
\end{tabular}

Dalam penelitian ini setiap variable yang diteliti diukur dengan menggunakan skala likert $(1-5)$. Skala likert digunakan untuk mengukur sikap, pendapat dan persepsi seseorang atau sekelompok orang tentang fenomena sosial (Winarno, 1982)

\section{Uji Reliabilitas dan validitas kuesioner}

Suatu kuesioner dikatakan reliabel atau handal jika jawaban seseorang terhadap pernyataan adalah konsisten atau stabil dari waktu ke waktu. (Ghozali, 2016: 47). Kuesioner dikatakan reliabel apabila memiliki nilai cronbach alpha $>0,6$. Sedangkan uji validitas digunakan untuk mengukur sah atau valid tidaknya suatu kuesioner. Suatu kuesioner dikatakan valid jika pertanyaan pada kuesioner mampu untuk mengungkapkan sesuatu yang akan diukur oleh kuesioner tersebut. (Ghozali, 2016: 52). Suatu kuesioner dikatakan valid apabila $\mathrm{r}$ hitung $>\mathrm{r}$ tabel.

\section{Uji Normalitas, Multikolinearitas dan Heterokedastisitas}

Uji normalitas dilakukan untuk mengetahui apakah di dalam sebuah regresi variabel dependen dan variabel independen mempunyai distribusi normal atau tidak. Uji normalitas yang digunakan dalam penelitian ini adalah dengan menggunakan uji statistic non-parametric Kolmogorov Smirnov (K-S). Uji multikolonieritas ini bertujuan untuk mengetahui apakah di tiap-tiap variabel saling berhubungan secara linier. Uji multikoloniaritas hanya dapat digunakan jika terdapat lebih dari satu variabel independen dalam model regresi. Uji multikoloniearitas. Multikolonieritas terjadi jika nilai tolerance $<0,10$ atau sama dengan VIF $>10$. Jika nilai VIF tidak ada yang melebihi 10, maka dapat dikatakan bahwa multikoloniearitas yang terjadi tidak berbahaya (lolos uji multikoloniearitas). Uji Heteroskedestisitas dimaksukan untuk menguji apakah di dalam model terdapat ketidaksamaan variance dari residual satu pengamatan ke pengamatan yang lain. Pengujian heteroskedastisitas dilakukan dengan mempergunakan metode scatterplot

\section{Analisis Regresi Linear Berganda}

Model regresi:

$\mathrm{Y}=\alpha+\beta_{1} \mathrm{X}_{1}+\beta_{2} \mathrm{X}_{2}+\beta_{3} \mathrm{X}_{3}+\beta_{4} \mathrm{X}_{4}+\beta_{5} \mathrm{X}_{5}+$ error

Dimana:

$\mathrm{Y}=$ Minat Investasi

$\alpha=$ Konstanta Parameter

$\mathrm{X}_{1}=$ Pengetahuan Investasi

$\mathrm{X}_{2}=$ Manfaat Investasi

$\mathrm{X}_{3}=$ Motivasi Investasi

$\mathrm{X}_{4}=$ Modal Investasi Minimal

$\mathrm{X}_{5}=$ Return Investasi

Sebelum melakukan uji hipotesis maka perlu dilakukan uji kecocokan model yaitu menggunakan Uji F dengan kriteria bila sig $<5 \%$. Selanjutnya melakukan uji hoptesis 
yaitu menggunakan Uji t, untuk menguji pengaruh masing masing variabel independen secara parsial terhadap variabel dependen dengan kriteria bila sig $<5 \%$. Teknik analisis selanjutnya adalah Adjusted $\mathrm{R}^{2}$ untuk mengetahui seberapa jauh kemampuan model dalam menerangkan variasi variabel dependen (Ghozali, 2016).

\section{HASIL DAN PEMBAHASAN}

\section{Hasil Uji Validitas}

Validitas dikatakan vailid apabila $\mathrm{r}$ hitung lebih besar dari $\mathrm{r}$ tabel. Dalam penelitian ini Pengujian validitas dilakukan dengan bantuan program SPSS. Adapun hasil uji validitas yang diperoleh penelitian menunjukan bahwa setiap item instrumen dari variabel Pengetahuan Investasi (X1), Manfaat investasi (X2), Motivasi Investasi (X3), Modal minimal Investasi (X4), Return Investasi (X5) dan Minat Investasi (Y) semuanya dinyatakan valid yang dibuktikan dengan nilai rhitung $>r_{\text {tabel }}(0.300)$ sehingga dapat dinyatakan valid dan dapat dilanjutkan ke analisis berikutnya.

\section{Hasil Uji Reliabilitas}

Suatu kuesioner dikatakan reliabel atau handal jika jawaban seseorang terhadap pernyataan adalah konsisten atau stabil dari waktu ke waktu. Adapun hasil uji reliabilitas variabel Pengetahuan Investasi (X1), Manfaat investasi (X2), Motivasi Investasi (X3), Modal minimal Investasi (X4), Return Investasi (X5) dan Minat Investasi (Y) semuanya dinyatakan reliabbel yang dibuktikan dengan nilai nilai koefisien cronbach alpha $>0,6$.

\section{Hasil Uji Normalitas}

Hasil uji normalitas pendekatan Kolmogorov-Smirnov dapat dilihat besarnya perolehan nilai Asymp.Sig (2tailed) adalah 0,200 >0,05, artinya data yang digunakan berdistribusi normal.

\section{Hasil Uji Multikolinearitas}

Berdasarkan hasil uji multikolinearitas tanpak bahwa nilai Tolerance Value pada variabel bebas $>$ dari nilai ketetapan yaitu 0,10 dan Nilai Variance Inflation Factors (VIF) variabel bebas $<$ dari nilai ketetapan yaitu 10 berarti tidak terjadi multikolinieritas terhadap data yang diuji

\section{Hasil Uji Heteroskedastisitas}

Dari grafik scatterplots terlihat bahwa titik-titik menyebar secara acak serta tersebar baik diatas maupun dibawah angka nopada sumbu Y. hal ini dapat disimpulkan bahwa tidak terjadi heteroskedastisitas pada model regresi, sehingga model regresi layak dipakai untuk memprediksi Minat Investasi (Y) berdasarkan masukan variabel independen Pengetahuan Investasi (X1), Manfaat Investasi (X2), Motivasi Investasi (X3), Modal Minimal Investasi (X4) dan Return Investasi (X5).

Analisis deskriptif dari data yang diambil untuk penelitian ini adalah jumlah dari hasil jawaban responden pada tiap tiap variabel pada 60 sampel dalam penelitian ini. Deskripsi variabel dalam statistik deskriptif yang digunakan pada penelitian ini meliputi nilai minimum, nilai maksimum, mean, dan standar deviasi dari satu variabel dependen yaitu Minat investasi dan lima variabel independen yaitu Pengetahuan Investasi, Manfaat Investasi, Motivasi Investasi, Modal Minimal Investasi dan Return Investasi. 
Tabel 3. Statistik Deskriptif

\begin{tabular}{|l|r|r|r|r|r|r|}
\hline & N & \multicolumn{1}{|c|}{ Range } & \multicolumn{1}{c|}{ Min } & \multicolumn{1}{c|}{ Max } & \multicolumn{1}{c|}{ Mean } & \multicolumn{1}{c|}{ Std. Deviation } \\
\hline Pengetahuan & 60 & 4 & 16 & 20 & 18.58 & 1.306 \\
\hline Manfaat & 60 & 8 & 12 & 20 & 16.27 & 2.090 \\
\hline Motivasi & 60 & 8 & 12 & 20 & 15.83 & 1.924 \\
\hline modal_minimal & 60 & 8 & 12 & 20 & 17.05 & 2.054 \\
\hline Return & 60 & 8 & 12 & 20 & 16.62 & 1.992 \\
\hline Minat & 60 & 8 & 12 & 20 & 16.38 & 1.932 \\
\hline Valid N (listwise) & 60 & & & & & \\
\hline
\end{tabular}

Berdasarkan tabel 3 tampak bahwa nilai minimum Pengetahuan Investasi sebesar 16 dan maksimum sebesar 20, dengan mean 18,58, pada standar deviasi sebesar 1,306. Karena nilai mean 18,8>16,8 dan rata-rata skor sebesar 4,6 berarti pengetahuan investasi mahasiswa tinggi.

Sedangkan nilai Manfaat Investasi, motivasi, modal_minimal, return serta minat investasi nilai minimal dan nilai maksimal sama yaitu masing-masing sebesar 12 dan sebesar 20. Namun nilai mean berviariasi antara 15,83 sampai dengan 17,05. Karena nilai mean modal minimal 17,05 $>16,8$ dan rata-rata skor sebesar 4,3 berarti modal minimal mahasiswa tinggi. Sebaliknya nilai mean manfaat investasi $(16,27)$, motivasi $(15,83)$, return $(16,62)$ dan minat investasi $(16,38)$ berkisar antara 13,6 sampai dengan 16,8 , berarti sedang.

Tabel 4. Hasil Uji Analisis Regresi Linear Berganda

\begin{tabular}{|c|c|c|c|c|c|c|}
\hline \multirow{2}{*}{\multicolumn{2}{|c|}{ Model }} & \multicolumn{2}{|c|}{ Unstandardized Coefficients } & $\begin{array}{l}\text { Standardized } \\
\text { Coefficients }\end{array}$ & \multirow[t]{2}{*}{$\mathrm{T}$} & \multirow[t]{2}{*}{ Sig. } \\
\hline & & $\mathrm{B}$ & Std. Error & Beta & & \\
\hline \multirow[t]{6}{*}{1} & (Constant) & 1.185 & 2.622 & & .452 & .653 \\
\hline & PENGETAHUAN & .053 & .159 & .036 & .336 & .738 \\
\hline & MANFAAT & .233 & .121 & .252 & 1.933 & .050 \\
\hline & MOTIVASI & .111 & .132 & .111 & .839 & .405 \\
\hline & MODAL MINIMAL & .232 & .130 & .247 & 1.786 & .080 \\
\hline & RETURN & .283 & .147 & .292 & 1.929 & .050 \\
\hline
\end{tabular}

a. Dependent Variable: MINAT

Sumber: output spss diolah

Berdasarkan hasil pengolahan regresi berganda yang ditunjukkan dalam tabel 4.14 maka diperoleh persamaan regresi berganda sebagai berikut:

$\mathrm{Y}=1.185+0.053 \times 1+0.233 \times 2+0.111 X 3+0.232 X 4+0.283 \times 5$

1. Pengetahuan investasi memiliki koefisien regresi dengan arah positif sebesar +0.053 hal ini menunjukkan setiap kenaikkan Pengetahuan Investasi satu satuan maka Minat Investasi akan mengalami kenaikkan sebesar 5.3 persen.

2. Manfaat investasi memiliki koefisien regresi dengan arah positif sebesar +0.233 hal ini menunjukkan setiap kenaikkan Manfaat Investasi satu satuan maka Minat Investasi akan mengalami kenaikkan sebesar 23.3 persen.

3. Motivasi Investasi memiliki koefisien regresi dengan arah positif sebesar +0.111 hal ini menunjukkan setiap kenaikkan Motivasi Investasi satu satuan maka Minat Investasi akan mengalami kenaikkan sebesar 11.1 persen.

4. Modal minimal investasi memiliki koefisien regresi dengan arah positif sebesar +0.232 hal ini menunjukkan setiap kenaikkan Modal Minimal Investasi satu satuan maka Minat Investasi akan mengalami kenaikkan sebesar 23.2 persen. 
5. Return Investasi memiliki koefisien regresi dengan arah positif sebesar +0.283 hal ini menunjukkan setiap kenaikkan Return Investasi satu satuan maka Minat Investasi akan mengalami kenaikkan sebesar 28.3 persen.

Tabel 5. Hasil Kecocokan Model (Uji F)

\begin{tabular}{|c|c|c|c|c|c|c|}
\hline \multicolumn{2}{|c|}{ Model } & Sum of Squares & Df & Mean Square & $\mathrm{F}$ & Sig. \\
\hline \multirow[t]{3}{*}{1} & Regression & 120.369 & 5 & 24.074 & 13.024 & $.000^{\mathrm{b}}$ \\
\hline & Residual & 99.814 & 54 & 1.848 & & \\
\hline & Total & 220.183 & 59 & & & \\
\hline \multicolumn{7}{|c|}{ a. $\quad$ Dependent Variable: MINAT } \\
\hline \multicolumn{7}{|c|}{ b. } \\
\hline
\end{tabular}

Sumber: Output SPSS 23

Hasil uji kelayakan model atau Uji F diperoleh nilai signifikansi sebesar $0.000<0.05$, menunjukkan bahwa uji model ini layak untuk digunakan pada penelitian.

Tabel 6. Hasil Uji Hipotesis (Uji t)

\begin{tabular}{|c|c|c|c|c|c|c|}
\hline \multirow{2}{*}{\multicolumn{2}{|c|}{ Model }} & \multicolumn{2}{|c|}{ Unstandardized Coefficients } & \multirow{2}{*}{$\begin{array}{c}\begin{array}{c}\text { Standardized } \\
\text { Coefficients }\end{array} \\
\text { Beta } \\
\end{array}$} & \multirow[t]{2}{*}{$\mathbf{T}$} & \multirow[t]{2}{*}{ Sig. } \\
\hline & & B & Std. Error & & & \\
\hline \multirow[t]{6}{*}{1} & (Constant) & 1.185 & 2.622 & & .452 & .653 \\
\hline & PENGETAHUAN & .053 & .159 & .036 & .336 & .738 \\
\hline & MANFAAT & .233 & .121 & .252 & 1.933 & .050 \\
\hline & MOTIVASI & .111 & .132 & .111 & .839 & .405 \\
\hline & MODAL MINIMAL & .232 & .130 & .247 & 1.786 & .080 \\
\hline & RETURN & .283 & .147 & .292 & 1.929 & .050 \\
\hline
\end{tabular}

Sumber: Output SPSS 23

Uji t dilakukan untuk mengetahui pengaruh variabel Pengetahuan Investasi, Manfaat Investasi, Motivasi Investasi, Modal Minimal Investasi dan Return Investasi terhadap Minat Investasi. Berdasarkan tabel 6 diperoleh hasil bahwa secara parsial semua variabel independent menunjukkan arah positif terhadap variabel dependent (minat invesatasi). Namun dari kelima variabel independent hanya variabel manfaat investasi dan return yang berpengaruh signifikan terhadap minat investasi, karena nilai signifikan sama dengan tingkat kesalahan yang ditetapkan $(0,05)$. Sedangkan variabel yang lain (pengetahuan, motivasi dan modal minimal tidak berpengaruh terhadap minat investasi.

Tabel 7. Hasil Adjusted R Square

\begin{tabular}{|c|c|c|c|c|}
\hline Model & $\mathrm{R}$ & R Square & Adjusted R Square & $\begin{array}{l}\text { Std. Error of the } \\
\text { Estimate }\end{array}$ \\
\hline 1 & $.739^{\mathrm{a}}$ & .547 & .505 & 1.360 \\
\hline \multicolumn{5}{|c|}{$\begin{array}{l}\text { a. Predictors: (Constant), RETURN, PENGETAHUAN, MANFAAT, MOTIVASI, } \\
\text { MODAL MINIMAL }\end{array}$} \\
\hline \multicolumn{5}{|c|}{ b. Dependent Variable: MINAT } \\
\hline \multicolumn{5}{|c|}{ Sumber: Output SPSS 23 Data Primer diolah } \\
\hline
\end{tabular}


Hasil pengujian Adjusted $R$ Square diatas menunjukkan bahwa nilai Adjusted $R$ Square adalah $50.5 \%$ variabel dependen yaitu Minat Investasi dijelaskan oleh lima variabel independen yaitu Pengetahuan Investasi, Manfaat Investasi, Motivasi Investasi, Modal Minimal Investasi dan Return Investasi. Sedangkan sisanya sebesar 49.5\% Minat Investasi dijelaskan oleh faktor faktor lain yang tidak dimasukkan kedalam model regresi.

\section{Pembahasan}

\section{Pengaruh Pengetahuan Investasi terhadap Minat Investasi}

Dalam proses keputusan berinvestasi, diperlukannya pengetahuan tentang pengembalian, risiko, tipe produk investasi, untuk mendapatkan investasi yang lengkap (Siahaan, 2011) Pengetahuan investasi yang tinggi memang cenderung mendorong investor untuk berinvestasi di Pasar Modal.

Hasil analisis statistik untuk variabel Pengetahuan Investasi diketahui bahwa keofisien regresi Pengetahuan Investasi bernilai 0.053. hasil statistik uji-t untuk variabel pengetahuan investasi diperoleh dengan nilai signifikan sebesar 0.738 sehingga lebih besar dari nilai toleransi kesalahan sebesar 0.05. dapat disimpulkan bahwa Pengetahuan Investasi tidak berpengaruh terhadap Minat Investasi mahasiswa Fakultas Ekonomi dan Bisnis Universitas Mataram. Hasil penelitian ini membuktikan bahwa Pengetahuan Investasi memiliki pengaruh positif tapi tidak signifikan terhadap minat investasi.

Penelitian ini sesuai dengan penelitian Malik (2017) yang menyatakan bahwa pengetahuan investasi berpengaruh positif dan tidak signifikan terhadap Minat Investasi. Hal tersebut menjelaskan bahwa pengetahuan investasi belum bisa membuktikan pengaruhnya terhadap minat investasi di Pasar Modal. Hal ini disebabkan karena calon investor maupun investor merasa edukasi ataupun sosialisasi oleh pihak Bursa Efek Indonesia tentang investasi di pasar modal kurang menarik.

\section{Pengaruh Manfaat investasi terhadap Minat Investasi.}

Menurut CSD NEWS dalam Hermawanti (2018) ada lima manfaat dalam investasi yang diperlu diketahui sebagai calon investor adalah potensi penghasilan jangka panjang, mengungguli inflasi, memberikan penghasilan tetap, menyesuaikan dengan perubahan kebutuhan, bisa berinvestasi sesuai dengan kebutuhan anda. Dengan demikian semakin banyak manfaat investasi yang dirasakan oleh investor maka semakin besar minat investor untuk berinvestasi di Pasar Modal.

Hasil analisis statistik untuk variabel Manfaat Investasi diketahui bahwa keofisien regresi Manfaat Investasi bernilai 0.233. hasil statistik uji-t untuk variabel Manfaat investasi diperoleh dengan nilai signifikan sebesar 0.050 sama dengan nilai toleransi kesalahan sebesar 0.05. dapat disimpulkan bahwa Manfaat Investasi berpengaruh positif dan signifikan terhadap Minat Investasi mahasiswa Fakultas Ekonomi dan Bisnis Universitas Mataram.

Penelitian ini sesuai dengan penelitian yang dilakukan oleh Karima (2018) yang menyatakan bahwa Manfaat investasi berpengaruh positif dan signifikan terhadap minat investasi. Hasil dari penelitian ini sejalan dengan teori manfaat investasi dimana investasi mempunyai manfaat dimasa yang akan datang seperti untuk memperoleh kehidupan yang lebih layak, untuk memenuhi kebutuhan-kebutuhan dimasa yang akan datang.

\section{Pengaruh Motivasi Investasi terhadap Minat Investasi}

Menurut Martoyo (2007) motivasi pada dasarnya adalah "proses untuk mencoba mempengaruhi seseorang agar melakukan sesuatu yang kita inginkan”. Dengan kata lain 
adalah dorongan dari luar terhadap seseorang agar mau melaksanakan sesuatu. Dengan demikian, semakin termotivasi seorang investor untuk berinvestasi maka semakin besar minat investor tersebut untuk berinvestasi di Pasar Modal.

Hasil analisis statistik untuk variabel Motivasi Investasi diketahui bahwa koefisien regresi Motivasi Investasi bernilai 0.111. hasil statistik uji-t untuk variabel motivasi investasi diperoleh dengan nilai signifikan sebesar 0.405 sehingga lebih besar dari nilai toleransi kesalahan sebesar 0.05. dapat disimpulkan bahwa Motivasi Investasi tidak berpengaruh terhadap Minat Investasi mahasiswa Fakultas Ekonomi dan Bisnis Universitas Mataram. Hasil penelitian ini membuktikan bahwa Motivasi Investasi memiliki pengaruh positif tapi tidak signifikan terhadap minat investasi.

Penelitian ini sesuai dengan penelitian Karima (2018) yang menyatakan bahwa Motivasi investasi berpengaruh positif dan tidak signifikan terhadap Minat Investasi. Hal tersebut menjelaskan bahwa Motivasi Investasi belum bisa membuktikan pengaruhnya terhadap minat investasi di Pasar Modal. Hal ini disebabkan karena calon investor maupun investor belum bisa terdorong oleh keinginan sendiri, ajakan teman sebaya ataupun dorongan keluarga untuk mulai berinvestasi.

\section{Pengaruh Modal Minimal Investasi terhadap minat investasi}

Surat Keputusan Nomor: Kep-00071/BEI/11-2013, surat keputusan tersebut merubah satuan perdagangan saham dalam 1 lot yang awalnya 500 lembar menjadi 100 dengan harga minimal saham yang diperdagangkan di BEI adalah Rp 50,- per lembar, dengan adanya kebijakan ini diharapkan membawa perubahan sehingga dapat menarik minat investor di pasar modal. Dengan demikian semakin rendahnya modal yang diperlukan untuk berinvestasi, maka semakin besar minat seorang investor untuk berinvestasi di Pasar Modal.

Hasil analisis statistik untuk variabel Modal Minimal Investasi diketahui bahwa keofisien regresi Modal Minimal Investasi bernilai 0.232. hasil statistik uji-t untuk variabel motivasi investasi diperoleh dengan nilai signifikan sebesar 0.080 sehingga lebih besar dari nilai toleransi kesalahan sebesar 0.05. dapat disimpulkan bahwa Modal Minimal Investasi tidak berpengaruh terhadap Minat Investasi mahasiswa Fakultas Ekonomi dan Bisnis Universitas Mataram. Hasil penelitian ini membuktikan bahwa Modal Minimal Investasi memiliki pengaruh positif tapi tidak signifikan terhadap minat investasi.

Penelitian ini sesuai dengan penelitian yang dilakukan oleh Hermawanti (2018) yang menyatakan bahwa Modal Minimal Investasi Tidak signifikan terhadap minat investasi. Para responden sangat memperhatikan modal awal yang dikeluarkan saat melakukan investasi, hal ini berkaitan dengan kestabilan keuangan bagi calon investor dan kesanggupan bagi calon investor mengenai nominal yang akan dikeluarkan pada saat mulai berinvestasi di Pasar Modal.

\section{Pengaruh Return Investasi terhadap Minat Investasi}

Return merupakan imbalan atau hasil yang diterima dari suatu kegiatan investasi. Return dan risiko dalam investasi memiliki hubungan positif, yaitu semakin tinggi risiko maka return yang diharapkan juga semakin tinggi (Jogiyanto, 2010). Dengan demikian, 
semakin besar Return yang diperoleh maka semakin besar minat investor untuk berinvestasi di Pasar Modal.

Hasil analisis statistik untuk variabel Return Investasi diketahui bahwa keofisien regresi Investasi bernilai 0.232. hasil statistik uji-t untuk variabel Return investasi diperoleh dengan nilai signifikan sebesar 0.050 sama dengan nilai toleransi kesalahan sebesar 0.05. dapat disimpulkan bahwa Return Investasi berpengaruh positif dan signifikan terhadap Minat Investasi mahasiswa Fakultas Ekonomi dan Bisnis Universitas Mataram.

Penelitian ini sesuai dengan penelitian yang dilakukan oleh Sulistyawati (2017) yang menyatakan bahwa Return investasi berpengaruh positif dan signifikan terhadap minat investasi. Sejalan dengan teori return dan risiko, return yang tinggi menghasilkan resiko yang tinggi dan sebaliknya return yang rendah maka akan menghasilkan resiko yang rendah, rata-rata calon investor sebelum melakukan investasi sangat memperhatikan resiko dan return yang ada dari sebuah investasi.

\section{KESIMPULAN DAN SARAN}

\section{Kesimpulan}

1. Variabel Pengetahuan Investasi menunjukkan arah positif, tapi tidak berpengaruh signifikan terhadap minat investasi pada mahasiswa Fakultas Ekonomi dan Bisnis Universitas Mataram.

2. Variabel Manfaat Investasi berpengaruh positif dan signifikan terhadap Minat Investasi pada mahasiswa Fakultas Ekonomi dan Bisnis Universitas Mataram.

3. Variabel Motivasi Investasi menunjukkan arah positif, tapi tidak berpengaruh signifikan terhadap Minat Investasi pada mahasiswa Fakultas Ekonomi dan Bisnis Universitas Mataram.

4. Variabel Modal Minimal Investasi menunjukkan arah positif, tapi tidak berpengaruh signifikan terhadap Minat Investasi pada mahasiswa Fakultas Ekonomi dan Bisnis Universitas Mataram.

5. Variabel Return Investasi berpengaruh positif dan signifikan terhadap Minat Investasi pada mahasiswa Fakultas Ekonomi dan Bisnis Universitas Mataram.

\section{Saran}

Hasil penelitian menunjukkan bahwa Variabel Pengetahuan Investasi, Manfaat Investasi, Motivasi Investasi, Modal Minimal Investasi dan Return Investasi hanya menjelaskan $54.7 \%$ terhadap Minat Investasi, sehingga perlu dianalisis variabel lain yang dapat memengaruhi Minat Investasi diluar model ini. 


\section{DAFTAR PUSTAKA}

Anoraga, Pandji. 2006. Pengantar Pasar Modal. Rineka Cipta

Gozali, I. 2016. Aplikasi Analisis Multivariet Dengan Program SPSS 23 (Edisi 8). Semarang: Badan Peneliti Universitas Diponegoro.

Halim, Abdul. 2005. Analisis Investasi. Edisi kedua. Jakarta: PT Salemba Empat

Hermanto. 2017. Perilaku Mahasiswa Ekonomi di Universitas Esa Unggul dalam melakukan investasi di pasar Modal. Jurnal ekonomi Universitas esa Unggul: Jakarta

Hermawanti., Nency. 2018. Analisis Faktor - Faktor Yang Mempengaruhi Minat Mahasiswa Untuk Berinvestasi Di Pasar Modal (Studi Pada Mahasiswa Prodi Akuntansi STIE Widya Gama Lumajang) Skripsi, STIE Widya Gama Lumajang.

Jogiyanto. Hartono. 2017. Teori Portofolio dan Analisis Investasi, Edisi kesebelas, BPFE, Yogyakarta

Karima., Laili. 2018. Analisis Faktor Faktor yang mempengaruhi minat mahasiswa untuk melakukan investasi di pasar modal syariah, Skripsi, Universitas Islam Indonesia, Yogyakarta

Khotimah, Khusnul., Sabar, Warsini., Yeni., Nuraini. 2017. Pengaruh Sosialisasi dan pengetahuan terhadap minat investor pada efek syariah di Pasar Modal (survey pada nasabah PT Danareksa Sekuritas cabang FE UI Depok), Politeknik Negeri Jakarta.

Kusmawati. 2011. Pengaruh Motivasi Terhadap Minat Berinvestasi Di Pasar Modal Dengan Pemahaman Investasi Dan Usia Sebagai Variabel Moderat.

Komang, Luh Merawati 2015. Kemampuan pelatihan Pasar Modal memoderasi pengaruh pengetahuan investasi dan penghasilan pada minat berinvestasi mahasiswa. Jurnal Ilmiah Akuntansi dan Bisnis: Universitas Udayana

Malik, Ahmad D. 2017. "Analisa Faktor-Faktor Yang Mempengaruhi Minat Masyarakat Berinvestasi Di Pasar Modal Syariah Melalui Bursa Galeri Investasi Uisi.” Jurnal Ekonomi dan Bisnis.

Nisa, Aminatun. 2017. Pengaruh Pemahaman Investasi, Modal Minimal Investasi, Dan Motivasi Terhada Minat Mahasiswa Berinvestasi Dipasar Modal (Studi Pada Mahasiswa Sekolah Tinggi Kesuma Negara). Skripsi. Blitar

Pajar., Rizky Chaerul. 2017. Pengaruh Motivasi Investasi Dan Pengetahuan Investasi Terhadap Minat Investasi Di Pasar Modal Pada Mahasiswa FE UNY. Skripsi, Universitas Negeri Yogyakarta

Riyadi, A. 2016. Analisis faktor-faktor yang mempengaruhi minat mahasiswa untuk berinvestasi di pasar modal (Studi mahasiswa fakultas ekonomi bisnis islam UIN Sunan Kalijaga Yogyakarta). Skripsi, Universitas Islam Negeri Sunan Kalijaga Yogyakarta.

Sugiyono. 2016. Metode Penelitian Kuantitatif, Kualitatif. Bandung, CV. AlfaBeta 
Sulistyawati., Dwi. 2017. Analisis Strategi Sosialisasi Pasar Modal Dan Pengaruhnya Terhadap Keputusan Masyarakat Berinvestasi Di Pasar Modal. Bengkulu

Tandio, Timothius, Widanaputra, 2018, Pengaruh pelatihan pasar modal, Return, Persepsi Risiko, Gender, dan kemajuan teknologi pada minat investasi mahasiswa, FEB Universitas Udayana, Denpasar

Yuliana, Indah. 2010. Investasi Produk Keuangan Syariah. Malang: UinMaliki Press.

Yuliana Susilowati 2017. Faktor-Faktor Yang Mempengaruhi Minat Mahasiswa Akuntansi Syariah Untuk Berinvestasi Di Pasar Modal Syariah (Studi Di IAIN Surakarta), Skripsi, IAIN SURAKARTA 